DOI: $10.2478 /$ lpts-2018-0022

ELECTRONIC COMMUNICATION

\title{
MATHEMATICAL ALGORITHM FOR PROCESSING MEASUREMENT RESULTS OF INTERNET ACCESS SERVICE IN THE SCOPE OF NET NEUTRALITY
}

\author{
I. Smirnova, E. Lipenbergs, V. Bobrovs \\ Department of Telecommunications, Riga Technical University, \\ 1 Kalku Str., Riga, LV-1658, LATVIA \\ inga.smirnova@sprk.gov.lv
}

\begin{abstract}
Since Regulation (EU) 2015/2120 of the European Parliament and of the Council came into force, Internet service providers have to fulfill various additional requirements in order to guarantee access to the open internet and provide transparent information to the end-users. Of the utmost importance is to ensure achievable, meaningful and comparable results of the internet quality indicators, particularly upload and download speed values. Regulation (EU) 2015/2120 stipulates that specific speeds should be indicated in the contracts: for fixed internet access service those are maximum, minimum, normally available and advertised speed and for mobile internet access service - estimated maximum and advertised speed. However, there are no common methods put in place to calculate required speed indicators that can lead to a large amount of noncomparable and unreviewable information and create difficulties for internet providers to describe quality indicators. Within the framework of the present research, a mathematical estimation algorithm has been elaborated and applied in order to ensure that required quality parameters are represented objectively and that they are intercomparable among different internet service providers. Unified calculation principle would foster end-user awareness of the meaning of quality indicators and also of the quality of received internet services. It would also facilitate the indication of the required information for internet service providers.
\end{abstract}

Keywords: internet access service, net neutrality, quality of service

\section{INTRODUCTION}

It is important to find a golden mean between user awareness and internet providers' ability to always ensure once indicated quality. What if sometimes a speed value is lower than specified minimum, or does not correspond to normally available, or it is several megabits per second lower than indicated maximum? Where is the borderline of acceptable noncompliance; and in which cases can an end-user take 
advantage of some little discrepancy? Wouldn't it force internet providers to specify lower quality indicators just in case? And wouldn't it in the end badly influence internet providers' businesses and give incomprehensible information to the end-users. The aim of the present research is to find an objective and equitable method for calculating the required speed values and implementing measurement processing algorithm that would be optimised for specific technology but at the same time would give the most comparable result and would be unified as much as possible in order to represent comparable data among various internet providers [6].

To compare quality parameter values among different internet service providers, as well as provide meaningful information to the end-users and reflect a realistic situation, some mathematical calculations should be implemented.

\section{PRACTICAL MEASUREMENTS}

To examine the best interpretation of speed parameter weight and find out the most unified approach in value acquisition, measurements have been conducted both for mobile and for fixed internet access services. Measurements have been performed during twenty-four hours in a one-week period. The frequency of the measurements has been approximately ten minutes [4], [5]. Though the Regulation does not require mobile internet service providers to indicate minimum and normally available speed values [2], [3], in the present research it has been assumed as a necessity to broaden end-users' understanding of common and possible minimum speed values.

Within the framework of the research, various speed tests have been performed in different types of internet networks; they all have shown a correlation between speed values during the day and internet technology (e.g., ADSL technology has stable but low speed values, Fiber - rather stable and high, Mobile - rather unstable that varies from low to high). In the research, measurements of two types of internet technologies have been studied: FTTH (Fiber to the Home) and 4G (fourth generation) mobile.

\section{A. Fixed Internet Measurements}

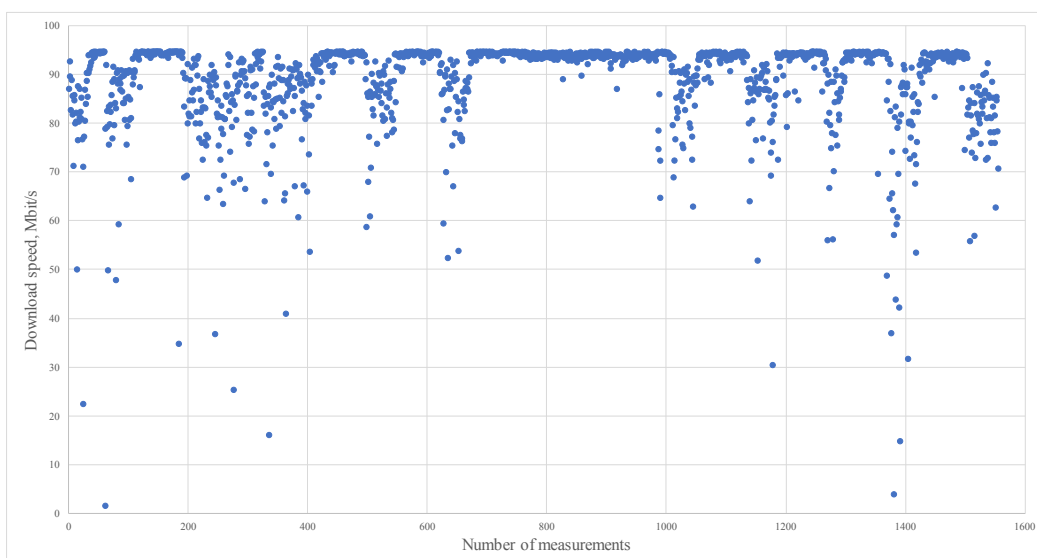

Fig. 1. Scatterplot of download speed distribution during the measurement period in the fixed network. 
Analysing measurement results of fixed internet access service, the stability of speed can be observed. Speed fluctuations mostly appear during peak hours, although the drop of the speed is not significant. Only few measurements show values that are lower than $60 \mathrm{Mbits} / \mathrm{s}$. The advertised maximum speed of this fixed internet test connection is $100 \mathrm{Mbits} / \mathrm{s}$.

\section{B. Mobile Internet Measurements}

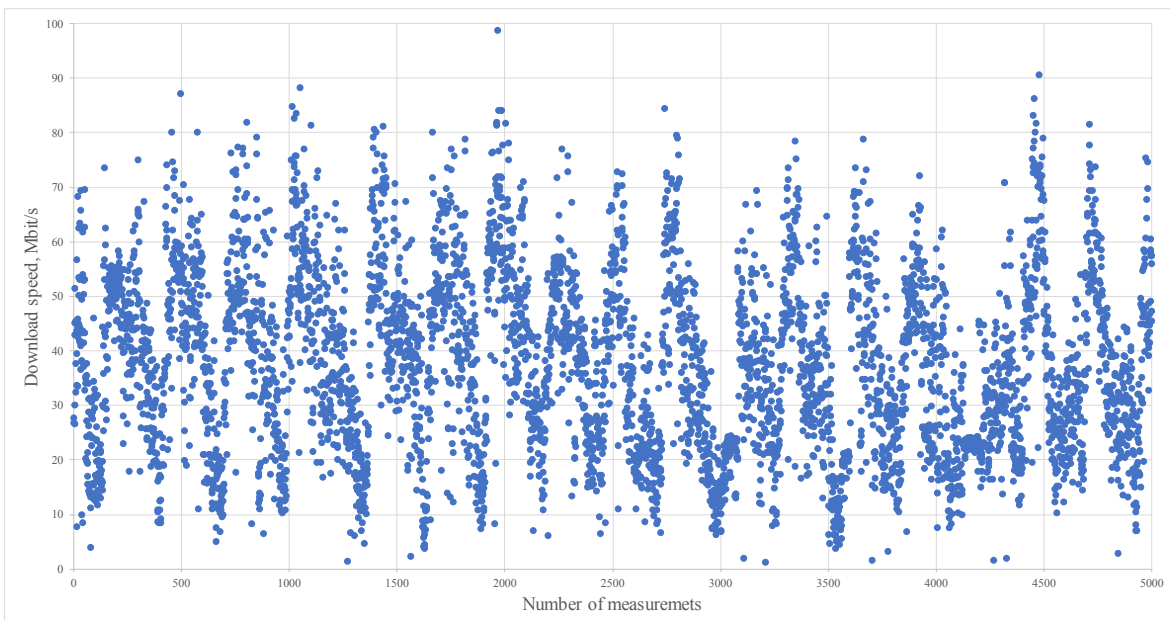

Fig. 2. Scatterplot of download speed distribution during the measurement period in the mobile network.

Analysing measurement results of mobile internet access service, it can be observed that speed is unstable during the day: it increases and decreases depending on the time of the day and varies from low to high in a wide range.

Quasiperiodicity of the download speed variation both in fixed and mobile networks can be explained by the end user's activity on the internet. Download speed lowers during the peak hours, particularly during the second half of the day and in the evenings when many end-users use the internet. Figures 1 and 2 show the download speed value of each measurement and represent the dynamics of its variation in time.

Although fixed and mobile internet speed values differ a lot, to give a comprehensible information to the end users and obtain a unified calculation approach for internet providers, it has been decided to apply a uniform calculation method both for fixed and for mobile internet access services.

\section{CALCULATION OF THE SPEED VALUES}

To observe the speed value distribution during the day, histograms have been made. These histograms show how often specific speed values occur during the day. The difference between the fixed and mobile internet is evident; they also have a non-normal distribution. Analysing the obtained results and evaluating the required 
target, it can be stated that although value distribution differs, the common calculation methods can be applied.

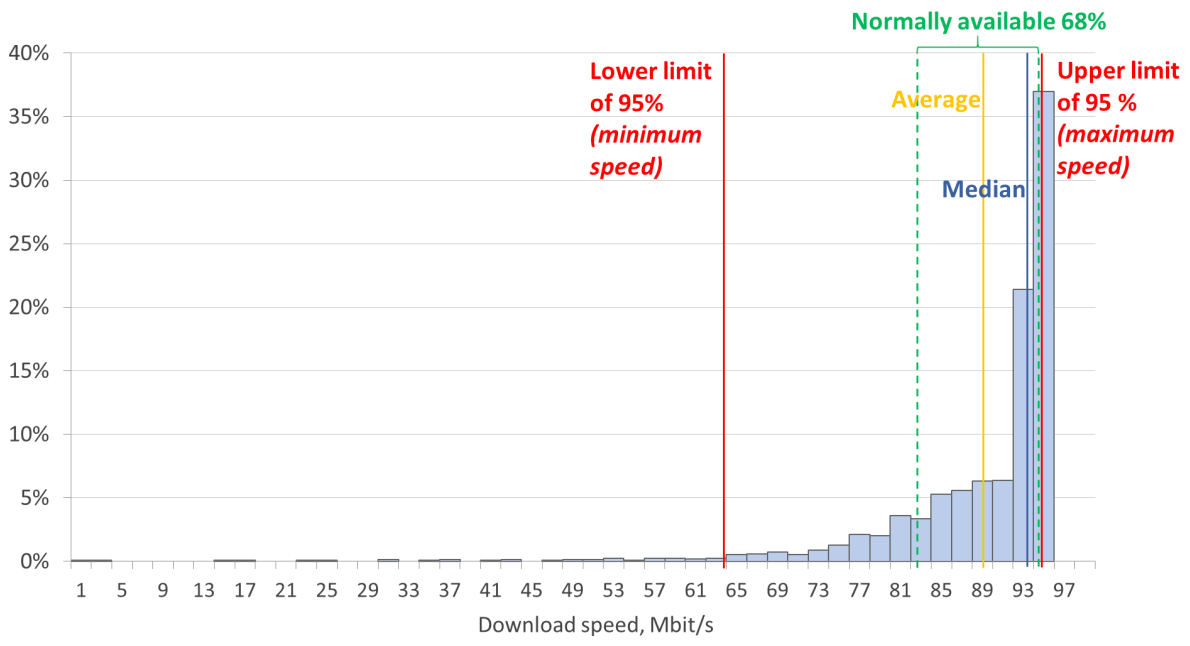

Fig. 3. Histogram of download speed values during the day in the fixed network.

The calculated download speed indicators of fixed internet access service are shown in Table 1.

Table 1

\section{Download Speed Values of the Fixed Internet}

\begin{tabular}{|c|c|c|c|c|c|c|c|c|c|c|}
\hline $\begin{array}{c}\text { Maxi- } \\
\text { mum }\end{array}$ & $\begin{array}{c}\text { Mini- } \\
\text { mum }\end{array}$ & $\begin{array}{c}\text { Lower } \\
\text { limit of } \\
95 \%\end{array}$ & $\begin{array}{c}\text { Upper } \\
\text { limit of } \\
95 \%\end{array}$ & Average & Median & $\begin{array}{c}\text { Stan- } \\
\text { dard } \\
\text { devia- } \\
\text { tion }\end{array}$ & $\begin{array}{c}\text { Aver- } \\
\text { age }+ \\
\text { standard } \\
\text { devia- } \\
\text { tion }\end{array}$ & $\begin{array}{c}\text { Average } \\
- \text { stan- } \\
\text { dard } \\
\text { devia- } \\
\text { tion }\end{array}$ & $\begin{array}{c}\text { Lower } \\
\text { imit of } \\
68 \%\end{array}$ & $\begin{array}{c}\text { Upper } \\
\text { limit of } \\
68 \%\end{array}$ \\
\hline 94.68 & 1.62 & 94.64 & 63.95 & 88.91 & 93.42 & 9.65 & 98.57 & 79.26 & 94.47 & 82.56 \\
\hline
\end{tabular}

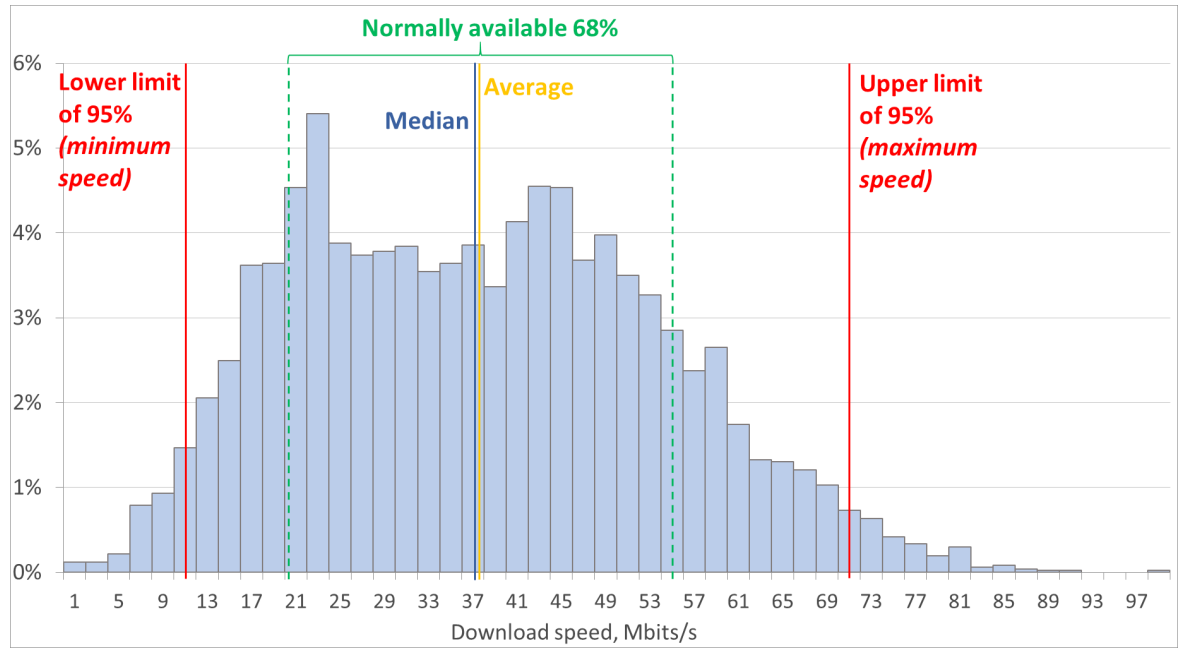

Fig. 4. Histogram of download speed values during the day in the mobile network. 
The calculated download speed indicators of mobile internet access service are shown in Table 2.

Table 2

Download Speed Values of the Mobile Internet

\begin{tabular}{|c|c|c|c|c|c|c|c|c|c|c|}
\hline $\begin{array}{c}\text { Maxi- } \\
\text { mum }\end{array}$ & $\begin{array}{c}\text { Mini- } \\
\text { mum }\end{array}$ & $\begin{array}{c}\text { Lower } \\
\text { limit of } \\
95 \%\end{array}$ & $\begin{array}{c}\text { Upper } \\
\text { limit of } \\
95 \%\end{array}$ & Average & Median & $\begin{array}{c}\text { Stan- } \\
\text { dard } \\
\text { devia- } \\
\text { tion }\end{array}$ & $\begin{array}{c}\text { Aver- } \\
\text { age }+ \\
\text { standard } \\
\text { devia- } \\
\text { tion }\end{array}$ & $\begin{array}{c}\text { Average } \\
- \text { stan- } \\
\text { dard } \\
\text { devia- } \\
\text { tion }\end{array}$ & $\begin{array}{c}\text { Lower } \\
\text { limit of } \\
68 \%\end{array}$ & $\begin{array}{c}\text { Upper } \\
\text { limit of } \\
68 \%\end{array}$ \\
\hline 98.66 & 1.17 & 70.96 & 10.61 & 37.69 & 37.15 & 16.44 & 54.13 & 21.25 & 54.85 & 20.32 \\
\hline
\end{tabular}

To avoid influence of some random values that occur rarely and do not reflect the overall situation, some confidence threshold should be determined. Fixed internet measurement results show that a majority of speed values are situated near the maximum value, whereas measured minimum values are distributed in the wide value range. Though they might occur, it happens rarely and does not influence the provided quality of service. Analogous situation takes place with the mobile internet; though the values are distributed in a wider range, the lowest and highest values occur rarely; thus, they do not give a realistic view on a minimum and maximum value. Therefore, to describe a realistic situation, it is advised to define a lower limit of value that would indicate an objective minimum value.

Analysing measurement results, it can be observed that values outside $95 \%$ of measurements appear most rarely; therefore, to discard non-common values and avoid their influence on the result it is advised to cut $2.5 \%$ values of the highest and lowest measurement values.

Figure 3 shows that in the fixed internet an average download speed value differs from median, and though more than a half of measurements $(58 \%)$ are in the range of $94 \mathrm{Mbit} / \mathrm{s}$ to $96 \mathrm{Mbit} / \mathrm{s}$, the other half (42\%) are widely distributed with lower values.

On the contrary, in the mobile internet (Fig. 4) an average speed value and median are almost the same, but quite a large number of values are higher than the average; thus, for an end-user it does not give an overall notion of speed values that can be achieved during the use of the internet access service.

Taking it into account, some more descriptive methods to indicate normally available speed should be established rather than determining only one speed value. In the present research, it has been decided to indicate normally available speed in the speed range. Normally available speed should be achievable sufficiently often during the day. However, one should consider a reasonable deviation from the indicated value that can occur at specific times of the day, e.g., at peak hours, during congestions etc. To determine an adequate proportion when defining normally available speed values, some mathematical algorithms should be put in place. In the research, it has been decided to apply an empirical rule to the distribution of speed values in order to establish the most unified approach that would be applicable for different internet access technologies. The empirical rule states that in normal distribution $68 \%$ of values are situated in the range of one standard deviation [1]. For the reason that measured speed distributions might differ from a normal distribution (as 
observed during the research, see Figs. 3 and 4) as well to facilitate calculations for internet service providers and implement a unified calculation approach, instead of calculation of standard deviation, it has been suggested to generalise the calculations and estimate $68 \%$ of values that are evenly distributed approximately around average value. For this reason, $16 \%$ of the range of the highest and lowest measurement values has been cut. Thereby it is considered that normally available speed is a speed that is distributed in $68 \%$ range of measurements performed during the day.

\section{CONCLUSION}

Determining the unified approach among internet providers gives a possibility to compare them and better understand the quality indicators. Due to the differences in technologies and achievable quality values, it is impossible to apply a completely universal approach. However, to get the information on realistic quality indicators and raise users' awareness of speed values they can achieve, a unified calculation algorithm should be implemented. The unified approach will serve as a method to gain comparable data, thus giving to public the meaningful information on different internet service providers. Indication of a normally available speed in the range gives a better insight of achievable speed values. It also provides flexibility to internet service providers to describe speed indicators, as well as safeguards them from endusers misusing a noncompliance with the indicated value that can sometimes occur by withdrawing from contract or claiming for indemnification. Representing normally available speed in the range gives end-users an understanding that the internet speed depends on several factors and normally available speed can vary in time.

\section{REFERENCES}

1. Peck, R., \& Devore, J.L. (2011). Statistics: The exploration and analysis of data (7th ed.). USA: Brooks/Cole, ISBN: 978-0-8400-5801-0.

2. REGULATION (EU) 2015/2120 OF THE EUROPEAN PARLIAMENT AND OF THE COUNCIL of 25 November 2015 laying down measures concerning open internet access and amending Directive 2002/22/EC on universal service and users' rights relating to electronic communications networks and services and Regulation (EU) No 531/2012 on roaming on public mobile communications networks within the Union.

3. BEREC Guidelines on the Implementation by National Regulators of European Net Neutrality Rules BoR (16) 127, August 2016.

4. Stafecka, A., Lipenbergs, E., Bobrovs, V., \& Sharashidze, T. (2017). Quality of service methodology for the development of internet broadband infrastructure of mobile access networks. In IEEE Conference Proceedings (pp.1-5), 19-21June 2017, Palanga, Lithuania, Kaunas: Kaunas University of Technology. ISBN 978-1-5386-0394-9.

5. Lipenbergs, E., Bobrovs, V., \& Ivanovs, G. (2016). Investigation of service quality of measurement reference points for the internet services on mobile networks. Latvian Journal of Physics and Technical Sciences, 53(5), 64-73. ISSN 0868-8257.

6. Lipenbergs, E., Bobrovs, V., \& Ivanovs, G. (2016). Quality of service measurements references investigation for the mobile internet services in the context of net neutrality framework. In Proceedings of 2016 Progress in Electromagnetics Research Symposium (PIERS 2016 Shanghai) (pp.4248-4252), 8-11August 2016, Shanghai, China. Piscataway: IEEE. ISBN 978-1-5090-6094-8. e-ISBN 978-1-5090-6093-1. 


\title{
INTERNETA PIEKLUVES PAKALPOJUMA MĒRĪJUMU REZULTĀTU APSTRĀDES MATEMĀTISKAIS ALGORITMS TİKLA NEITRALITĀTES JOMĀ.
}

\author{
I.Smirnova, E.Lipenbergs, V.Bobrovs
}

Kopsavilkums

Kopš Eiropas Parlamenta un Padomes Regula (ES) 2015/2120 stājās spēkā, interneta pakalpojuma sniedzējiem jāievēro vairākas papildu prasības, lai nodrošinātu piekḷuvi atvērtam internetam un sniegtu galalietotājiem caurskatāmu informāciju. Visbūtiskākais ir sniegt jēgpilnu un salīdzināmu informāciju par sasniedzamiem interneta kvalitātes rādītājiem, jo īpaši par lejupielādes un augšupielādes ātrumiem. Regula (ES) 2015/2120 nosaka, kādus pieslēguma ātruma rādītājus interneta pakalpojuma sniedzējiem ir jānorāda līgumos ar galalietotāju, t.i.: fiksētam interneta piekḷuves pakalpojumam jānorāda maksimālais, minimālais, parasti pieejamais un reklamētais ātrums, savukārt mobilam interneta piekḷuves pakalpojumam paredzamais maksimālais un reklamētais ātrums. Tomēr kopējas metodes ātrumu rādītāju aprēķinam nav noteiktas, līdz ar to, iespējams, radot nepārskatāmas un nesalīdzināmas informācijas daudzumu, kā arī radot grūtības interneta pakalpojuma sniedzējiem atspoguḷot kvalitātes rādīiājus. Pētījumā tika atrasts un piemērots matemātisks aprēķinu algoritms, ar kura palīdzību norādāmās lejupielādes ātruma kvalitātes vērtības būtu objektīvi atspoguḷotas un savstarpēji salīdzināmas starp dažādiem pakalpojuma sniedzējiem. Vienots aprēķinu princips veicinātu lietotāju izpratni par vērtîbu nozīmi un saņemtā pakalpojuma kvalitāti, kā arī atvieglotu interneta pakalpojuma sniedzējiem minētās informācijas norādīšanu.

16.02.2018. 